\title{
Democratic Regimes and Cabinet Politics: a Global Perspective
}

\author{
Octavio Amorim Neto \\ David Samuels
}

\begin{abstract}
Cabinets link the executive and legislative branches, thus linking parties and government, in all democracies. Variation in cabinet appointments can help explain differences in policy-making and interest representation across different democratic regimes. We explore how variation in the separation of executive and legislative powers affects two critical questions for the study of cabinets: (1) to what extent are portfolios given to party members versus independent technocrats or political cronies of the chief executive, and (2) to what extent do executives follow "Gamson's Law" and distribute portfolios proportionally to parties in the government coalition? We argue that executives face strong incentives to appoint partisan and proportional cabinets only when they depend on legislative confidence. In contrast, under the separation of powers, executives have stronger incentives to appoint non-partisans and to distribute portfolios non-proportionally. Our results confirm that cabinets tend to be less partisan and proportional under pure presidentialism compared to parliamentarism and semi-presidentialism. These findings have substantial implications for understanding how the separation of powers affects governance.
\end{abstract}

Cabinets link the executive and legislative branches of government - thereby linking parties to government - in all democracies. Variation in patterns of cabinet appointments can thus provide a window to understand fundamental differences across democratic regimes in policy-making and interest representation. Therefore an important question for comparativists to consider is the extent to which cabinet dynamics differ not simply across countries but whether systematic differences exist across democratic regimes. Thus, this paper tackles two fundamental questions about cabinet portfolio allocation: who gets ministries: party stalwarts or independents (be they technocrats or political cronies of the chief executive); and are portfolios distributed proportionally to parties in the government coalition?

Do cabinet partisanship and proportionality differ systematically across democratic regimes? This is an important issue because if the answer is positive, then the incentives for coalition formation will also differ - as will the actual functioning of coalition government, whether minority or majority. These differences, in turn, should have systematic effects on the policy process and the nature of interest representation. In short, when comparing across all forms of democracy, the question is not simply whether a coalition will form or what the size the coalition will be, but parties' relative influence to propose and implement policies and represent the interests that got them elected. Because of "parliamentary accountability" in parliamentary systems, legislative parties play a direct role in interest representation and in policy formulation, through their control over executive survival. Whether the government is majority or minority, single-party or coalition, parties dominate the political process. Cabinet partisanship and proportionality are important because they indicate the extent of the chief executive's autonomous influence over cabinet formation and the policymaking process. If the chief executive has greater autonomous influence, the legislative/ 
parliamentary parties have less. Such differences cut to the heart of questions of democratic representation and policy-making.

This paper explores the hypothesis that the key factor determining variation in cabinet partisanship and proportionality is the system of government. Three democratic regimes can be arrayed along a continuum from weakest to strongest head of state in terms of influence over cabinet appointments: parliamentary systems (both monarchies and republics), semi-presidential systems, and pure presidential systems. As heads of state gain autonomy from the legislature, they tend to possess relatively greater autonomous powers, as well as to appoint and dismiss cabinet ministers. These autonomous powers tend to be correlated with executives' ability to employ different governing strategies - from a purely legislative strategy of seeking to pass laws through the normal legislative process to an extra-legislative strategy through the use of decrees and other unilateral powers. The purely legislative strategy involves parties to a significant extent. In contrast, parties' roles are relatively more constrained when presidents adopt a decree-making strategy. The question at hand is the extent to which differences in executive autonomy impact cabinet partisanship and proportionality.

We show that although differences in cabinet partisanship and proportionality exist across all regimes, the clearest difference is between pure presidentialism and all other forms of democracy. This suggests that although differences do exist between cabinets in parliamentary versus semipresidential systems (Druckman and Roberts 2003; Amorim Neto and Strøm 2006), the only substantial cross-system difference in terms of the nature of cabinet appointments is between pure presidentialism and all other forms of democracy. We discuss the implications of this finding in the conclusion.

\section{Sources of Variation in Cabinet Appointment Strategy Across Democratic Regimes}

We explore the factors associated with two outcomes: (1) the share of non-partisans in the cabinet; and (2) the aggregate rate to which portfolios are distributed proportionally to each party's share of seats in the government coalition, what Amorim Neto (2002; 2006) labels coalescence. Why should one expect executives' cabinet appointment strategies to vary given differences in constitutional structure? Scholars have suggested that several "smaller" institutional variables help explain intra-regime variation in cabinet composition. For example, Carroll and Cox (2007) show that when parties sign a pre-electoral coalition, cabinet proportionality in majority governments in pure parliamentary systems is strengthened. (Of course, cabinet proportionality is never very weak in parliamentary systems.) In parliamentary and semi-presidential systems, Amorim Neto and Strøm (2006) find that presidential powers affect the share of non-partisan cabinet ministers. Similarly, Amorim Neto (2006) finds that the size of the president's party, extremist presidents, presidents' powers, and electoral cycles affect cabinet partisanship and coalescence.

These variables may matter, but in cross-regime perspective they may matter only a bit. In this paper we concentrate on the "largest" variable, the constitutional fusion or separation of executive and legislative power, in conjunction with executives' autonomous powers, to illustrate how inter-regime variation matters for cabinet dynamics, and by implication for government output. Covering a much larger sample of countries also provides a broader perspective on the factors that drive variations in cabinet composition across countries.

In any country, government output is a function of executives' ability to enact their policy goals. Cabinet ministers everywhere serve two purposes, to greater or lesser degrees: they help build support for legislative proposals that fall under the purview of their portfolio, and they oversee government departments that implement legislation. Executives appoint ministers who they believe will best fulfill their goals in terms of proposing and implementing legislation, given existing constraints. Thus in any political system, executives' preferences concerning cabinet composition reflect (1) their policy preferences over outcomes; and (2) under majority rule, the extent of their need to negotiate with other actors to obtain those outcomes - including members of their own party.

We have no reason to believe that executives' policy preferences upon assuming office differ systematically across political regimes. However, the extent of an executive's need to negotiate with other actors in order to obtain his or her preferred outcomes might. Simplifying, let us assume that executives possess two policy-making strategies: they can seek to enact their policy goals through statutes, or through executive prerogatives. The "statutory" strategy requires that a proposal pass through the normal legislative process: the chief executive proposes a bill by sending it to the legislature, which he or she hopes will convert it into a law. This strategy signals that the chief executive is willing to heed legislators' views and interests. In contrast, the "executive prerogative" path may not require the legislature's involvement at all. For example, in some countries chief executives have the power to issue decrees that have the force of law. This strategy signals that the chief executive prefers to pay relatively less attention to legislators' interests and preferences.

Obviously, chief executives may possess a mix of strategies; it is also not the case that differences across democratic regimes may be so cut and dry. Yet we draw this distinction starkly to explore the hypothesis that a general tendency exists across 
democratic regimes: If chief executives know that the statutory strategy is the only way to implement their policy goals, they must seek to develop a strong relationship with a legislative majority. In contrast, executives who have relatively greater autonomy from the legislature to propose and implement policy face relatively weaker incentives to build a relationship with legislative parties. These incentives are obviously never wholly absent, but they may be substantially weaker from one system to the next.

"Parliamentary accountability" is the source of the near-perfect proportionality between seat shares and cabinet shares that Gamson (1961) and Browne and Franklin (1973) noted decades ago: prime ministers typically possess few autonomous prerogatives and instead depend wholly on legislative parties for both their government's survival and their legislative success. Consequently, they must adopt a "statutory" strategy and appoint wholly partisan and coalescent cabinets. Partial exceptions to this law do exist, as Carroll and Cox (2007) showed, but these do not disprove the rule that proportionality is higher in pure parliamentary systems, as we will show below.

In contrast, at the other end of the continuum, the chief executive's survival does not depend on legislative confidence in any pure presidential system. Under the separation of powers presidents could use the "bully pulpit" to advocate politically radical proposals, and they can manage the bureaucracy as they see fit, without fear of being tossed from office by their own party or by a majority formed by other parties. Moreover, many presidents possess autonomous powers that may give them the ability to implement policy independently of the legislative majority, or the ability at least to veto a legislative majority's proposal. Presidents also typically posses the power to freely appoint and dismiss cabinet ministers, again independently of their own survival.

In pure presidential regimes cabinet appointment strategies thereforeultimately depend on the president's prior beliefs about the overall efficacy of the statutory versus the prerogative approach to policy-making. On the one hand, given ideological differences between presidents and assemblies, institutional rules, and/or the partisan composition of the legislature, a president might believe that a "statutory" strategy is optimal, and thus that cabinet portfolios should be distributed to maximize the chances of legislative approval of statutes. In such a situation, the distribution of portfolios would resemble the dynamic under pure parliamentarism, and presidents will appoint a wholly partisan cabinet in exact proportion to the contribution each party makes to the legislative majority. On the other hand, if presidents decide to pursue their policy goals at least in part through decrees or other unilateral powers, they face far weaker incentives to appoint a partisan, coalescent cabinet, and instead could fill portfolios with non-partisan technocrats, cronies, or interest group representatives (Amorim Neto 2006).
Our expectations regarding cabinet partisanship and proportionality are fairly straightforward: executives' cabinet appointment incentives under pure parliamentarism should most clearly differ from the incentives under pure presidentialism. Under parliamentary systems of government, prime ministers cannot afford to ignore the preferences of the parties that make up their government (except under rare circumstances). Alienating legislative support is asking for a no-confidence vote, which might result in the prime minister's removal from office. In between pure presidential systems and parliamentary systems, we expect semi-presidential systems to represent something of a middle ground. ${ }^{1}$ In these systems, the prime minister depends on parliamentary confidence, but both the president and the prime minister typically have a veto over cabinet appointments (Almeida and Cho 2003; Amorim Neto and Strøm 2006; Schleiter and Morgan-Jones 2009). Thus, we expect the degree of partisanship and proportionality under semi-presidentialism to fall somewhere in between parliamentary and presidential forms of government.

As noted at the start of this section, we test this general hypothesis on two dependent variables: (1) cabinet partisanship, or the share of non-partisans in the cabinet; and (2) cabinet coalescence, or the degree to which portfolios are distributed proportionally to each party's share of seats in the government coalition. For each of these measures, we expect our general hypothesis about inter-regime differences to be modified by the autonomous institutional powers that chief executives possess. This generates two key hypotheses for both dependent variables: first, that cabinet partisanship and coalescence will be highest in pure parliamentary regimes and lowest in pure presidential regimes; and second, that executives' autonomous powers under all democratic regimes affect cabinet partisanship and proportionality. These two hypotheses have very different implications: If we find both hypotheses to be true, independently of each other, then regimetype affects cabinet dynamics no matter how weak or powerful the chief executive. Yet if we find the first to be false but the second to be true, then the separation of powers only has an impact on cabinet politics to the extent that chief executives have autonomous powers.

\section{Case Selection}

To explore our hypotheses we obtained cabinet appointment information from as many countries as possible. We thus gathered data from 1980-2000 from all the countries in Woldendorp et al. (2000) that were semi-democratic or better according to Freedom House (and for which we could find data). ${ }^{2}$ For the countries in the Americas, we included all those that were democratic or semi-democratic according to Mainwaring et al. (2001) for which we were able to find cabinet and party system data.

According to Woldendorp et al. (2000, p. 10), a new cabinet in a parliamentary monarchy, parliamentary 
republic, or semi-presidential republic should be counted when one or more of the following occurs:

(1) a change of prime minister;

(2) a change in the party composition of the cabinet; or

(3) resignation in an inter-election period followed by re-formation of the government with the same Prime Minister and party composition.

In a presidential system, the criteria differ slightly. Because presidential cabinets are not accountable to the legislature, a new legislative election (i.e. a midterm election) does not necessarily imply the formation of a new presidential cabinet. Thus we defined a new presidential cabinet when one of the following occurs:

1) the inauguration of a new president; or

2) a change in the party composition of the cabinet.

Given these criteria, we gathered information on 437 cabinets in 57 countries, distributed as follows:

Table 1. Number of Cases by Regime Type

\begin{tabular}{lccc} 
Regime Type & Number of Cabinets & \% of Total \\
Parliamentary Monarchies & 245 & 55.30 \\
\hline Semi-Presidential Republics & 92 & 20.77 \\
\hline Presidential Republics & 106 & 23.93 \\
\hline
\end{tabular}

We used a variety of primary and secondary sources to identify cabinet ministers' party affiliation or lack thereof, which we then used to calculate partisanship and proportionality. (Appendix One lists these sources.)

\section{Exploring Cabinet Partisanship}

Again, we are not interested in variation in the partisanship of cabinets within countries. We calculate country-averages in order to explore aggregate crossregime patterns. Table Two lists the number of cases for each country and the average percentage of non-partisan ministers in the cabinets in each of the 57 countries in the sample, in ascending order in two columns.

Table 2. Countries, Cases, and Average $\%$ of Non-Partisan Cabinet Ministers

\begin{tabular}{|c|c|c|c|c|c|c|c|}
\hline Country & Cabinets & Regime Type & Avg. \% Noparty & Country & Cabinets & Regime ype & Avg. \% Noparty \\
\hline Belgium & 10 & PARL & 0.00 & Japan & 16 & PARL & 1.49 \\
\hline Botswana & 5 & PARL & 0.00 & Uruguay & 6 & PRES & 1.52 \\
\hline Germany & 8 & PARL & 0.00 & Costa Rica & 6 & PRES & 1.72 \\
\hline Australia & 8 & PARL & 0.00 & Romania & 6 & SEMI & 3.13 \\
\hline Canada & 7 & PARL & 0.00 & Mexico & 2 & PRES & 3.57 \\
\hline Czech & 3 & PARL & 0.00 & Austria & 7 & SEMI & 3.63 \\
\hline Denmark & 9 & PARL & 0.00 & Italy & 18 & PARL & 4.99 \\
\hline Estonia & 6 & PARL & 0.00 & Colombia & 11 & PRES & 5.61 \\
\hline Guyana & 5 & PARL & 0.00 & Slovakia & 6 & PARL & 6.26 \\
\hline Iceland & 7 & SEMI & 0.00 & Portugal & 8 & SEMI & 6.52 \\
\hline India & 8 & PARL & 0.00 & Chile & 5 & PRES & 6.67 \\
\hline Ireland & 10 & SEMI & 0.00 & France & 13 & SEMI & 6.71 \\
\hline Jamaica & 6 & PARL & 0.00 & Argentina & 6 & PRES & 7.04 \\
\hline Lithuania & 4 & SEMI & 0.00 & Spain & 7 & PARL & 7.04 \\
\hline Luxembourg & 5 & PARL & 0.00 & Macedonia & 2 & SEMI & 7.14 \\
\hline Malta & 5 & PARL & 0.00 & Hungary & 3 & PARL & 8.89 \\
\hline Netherlands & 6 & PARL & 0.00 & Latvia & 3 & PARL & 9.52 \\
\hline New Zealand & 12 & PARL & 0.00 & Namibia & 2 & SEMI & 9.61 \\
\hline Norway & 10 & PARL & 0.00 & Greece & 12 & PARL & 13.37 \\
\hline Slovenia & 4 & SEMI & 0.00 & Panama & 7 & PRES & 17.77 \\
\hline South Africa & 2 & PARL & 0.00 & Bolivia & 8 & PRES & 20.49 \\
\hline Sri Lanka & 6 & SEMI & 0.00 & Czechoslovakia & 2 & PARL & 20.83 \\
\hline Switzerland & 19 & PARL & 0.00 & Poland & 8 & SEMI & 28.46 \\
\hline UK & 6 & PARL & 0.00 & Bulgaria & 6 & SEMI & 33.82 \\
\hline USA & 5 & PRES & 0.00 & Peru & 9 & PRES & 40.83 \\
\hline Israel & 16 & PARL & 0.37 & Venezuela & 6 & PRES & 43.67 \\
\hline Sweden & 10 & PARL & 0.59 & Brazil & 15 & PRES & 46.94 \\
\hline Finland & 9 & SEMI & 0.74 & Ecuador & 20 & PRES & 65.31 \\
\hline Turkey & 12 & PARL & 1.47 & & & & \\
\hline
\end{tabular}

PARL $=$ Parliamentary $/$ SEMI $=$ Semi-Presidential $/$ PRES $=$ Presidential 
Eyeballing Table Two reveals that nearly all countries that always have fully partisan cabinets are parliamentary, and that only one presidential system, the USA, falls below the median percentage of non-partisan ministers, which is Turkey's value of $1.47 \%$. In contrast, several presidential systems have far higher average proportions of non-partisan ministers. For example, in both Venezuela and Brazil, nearly half of all cabinet ministers do not belong to a political party, and nearly two-thirds of all cabinet ministers in Ecuador are non-partisans. Note also that only eight of the 28 cases above the median value are parliamentary systems.

After gathering the information by cabinet and by country, we then calculated the percentage of nonpartisan ministers for each regime type, as follows:

Table 3. Average Percentage of Non-Partisan Ministers by Regime Type

\begin{tabular}{lc}
\multicolumn{1}{c|}{ Regime Type } & Percentage (Std. Dev.) \\
\hline Parliamentary & $2.47(4.99)$ \\
\hline Semi-Presidential & $7.21(10.69)$ \\
\hline Presidential & $20.87(21.47)$ \\
\hline
\end{tabular}

Table Three reveals that all else equal, the stronger the executive and the more voters have a direct role in the executive's investiture, the higher the proportion of non-partisans in the cabinet. Note that the relationship between regime type and the percentage of non-partisan ministers appears to be non-linear, in that the average percentage of non-partisan ministers increases only slightly from parliamentary monarchies to semi-presidential systems, but takes a much larger jump from semipresidential systems to pure presidential systems. ${ }^{3}$ The institutional leap from semi-presidentialism to pure presidentialism appears to have the largest effect on the relative degree of partisan composition of the cabinet.

To what extent to these differences hold up to multivariate analysis? Here we simply wish to see if any control variable confounds the impression Table Three provides that cabinets in presidential systems are far less "partisan." Existing research suggests that several non-regime variables may be associated with cabinet partisanship. The first is the degree of legislative party fragmentation. When the legislature has many parties, the cost of including additional partners in a coalition tends to increase. This process works similarly, but for different reasons, in all regime types. For example, in presidential regimes high fragmentation tends to decrease the size of the chief executive's party, which makes passing legislative proposals relatively more difficult, all else equal. This encourages presidents to prefer to govern through their unilateral policymaking instruments and weakens incentives to appoint partisan cabinets (Amorim Neto 2006). In parliamentary systems, high fragmentation tends to lead to stalemated legislatures, which favors the formation of occasional care-taker cabinets relatively more likely to be staffed by non-partisans (Linz 1997, 11). In semi-presidential regimes, when parliament's ability to bargain is inhibited by party fragmentation, presidential influence rises, and party control over portfolios declines (Schleiter and Morgan-Jones 2009). Independently of regime type, we therefore expect chief executives to have greater incentives to bring non-partisans into the cabinet under conditions of high legislative fragmentation. ${ }^{4}$ We use the standard measure of fragmentation, the effective number of legislative parties (Laakso and Taagepera 1979).

The second variable is the quality of the bureaucracy. Independently of regime type, a more professional bureaucracy should be associated with a higher cabinet partisanship because the chief executive has less worry about needing to bring policy expertise into the executive branch (Graham 1997; Peters 1997). In contrast, an executive in a country with a low-quality bureaucracy might have stronger incentives to appoint technocrats to the cabinet in order to accomplish his or her policy goals. We therefore included a variable assessing bureaucratic quality. For this variable we use a measure that varies from 0 to 4 , taken from an index of political risk that has been used by the World Bank and in the private sector since 1980 (PRS Group 2004; for use in academic research, see Rauch and Evans 2000). High values are associated with high-quality bureaucracies, i.e. those that are relatively politically autonomous and that have solidly established mechanisms for recruitment and training. Low scores, in contrast, are associated with bureaucracies that suffer from substantial political interference in terms of policy implementation and administration. We use the average score for each country. (The scores for each country do not to vary much over time).

Third, scholars have suggested that aggregate economic conditions affect the likelihood of technocrats entering the ministry. In a global sample, negative economic conditions should increase the likelihood of technocrats and/or independents entering the ministry. We use the annual rate of GDP growth as a proxy for economic performance (World Bank 2006). ${ }^{5}$

Fourth, we also included the number of years that the country has been democratic since 1946 (AGE) (Banks and Muller eds. 1998). One might hypothesize that the more experience a country has with democracy, the more institutionalized the party system will be. If parties and patterns of party competition are relatively more institutionalized, chief executives might have relatively greater incentives to appoint partisan ministers. In contrast, if parties and patterns 
of competition are fluid, executives might face weaker incentives because parties would be relatively less reliable as legislative allies or because they lack experienced personnel to manage certain ministries. Therefore, the older the democracy, the more partisan the cabinet.

Finally, as noted, several scholars suggest that executives' autonomous powers may be associated with cabinet partisanship. Here we extend Amorim Neto's (2006) and Amorim Neto and Strom's (2006) hypotheses for pure and semipresidential systems to all systems: independently of regime type, the extent to which executives can implement policy without legislative interference suggests that they can ignore partisan concerns when constructing a cabinet, and instead appoint non-partisans and/or personal cronies. We measure this variable in ways similar to Shugart and Carey (1992) or Metcalf (2000), for example, by exploring countries' constitutions and measuring the relative balance of agenda and veto powers between the executive and legislative branches of power. ${ }^{6}$ We gathered the information for the construction of our index from the database of constitutions maintained by the University of Richmond at http://confinder.richmond.edu/ index.php. Full information on the components of our index can be found in Appendix Two. ${ }^{7}$

Here, our dependent variable is the average percentage of non-partisan ministers in each cabinet in each country. As this is a continuous variable bounded between zero and one, Tobit is the appropriate regression technique. The regression model includes (1) dummy variables for each democratic system; (2) the average degree of legislative fragmentation in each country; (3) a measure of bureaucratic quality; (4) the age of democracy; 5) the economic growth rate; and (6) our measure of executives' autonomous powers. We excluded parliamentary systems as the base category. The results appear in Table Four. ${ }^{8}$

Table 4. Factors Associated with Cabinet Partisanship (Tobit Regression)

\begin{tabular}{lcc|cc} 
Variable & Coefficient (S.E.) & $p>|\mathbf{t}|$ & Coefficient (S.E.) & $p>|\mathbf{t}|$ \\
\hline Presidential & $.189(.081)$ & .025 & $.292(.067)$ & .000 \\
\hline Semipresidential & $.067(.055)$ & .229 & $.087(.057)$ & .131 \\
\hline Legislative Fragmentation & $.035(.015)$ & .023 & $.037(.015)$ & .019 \\
\hline Bureaucratic Quality & $.013(.034)$ & .708 & $.006(.036)$ & .877 \\
\hline Age of Democracy & $-.001(.002)$ & .513 & $-.002(.002)$ & .163 \\
\hline Economic Growth & $-.027(.01)$ & .012 & $-.024(.011)$ & .030 \\
\hline Executive Powers & $.015(.008)$ & .064 & -- & -- \\
\hline Constant & $-.199(.104)$ & .062 & $-.135(.104)$ & .201 \\
\hline $\mathrm{N}$ & 57 & & 57 & \\
\hline LR chi-squared & 45.27 & & 41.77 & \\
\hline$p>$ chi-squared & 0.000 & & 0.000 & \\
\hline Log-likelihood & 6.946 & & & \\
\hline pseudo-r ${ }^{2}$ & 1.443 & & & \\
\hline
\end{tabular}

Dependent variable: percentage of non-partisans in the cabinet

We use two models, one that includes the variable measuring executives' powers and one that does not. The reason for running two models is that "executive powers" is highly correlated with pure presidentialism (.74). The results of the two models reveal that controlling for executive powers does not eliminate the difference between presidentialism and the base category. In short, these results support the hypothesis that cabinet partisanship is substantially lower in presidential systems. However, semi-presidentialism does not differ from the base category. ${ }^{9}$ In addition, as predicted, the proportion of non-partisans in the cabinet tends to increase as legislative fragmentation increases in all systems, and executives have greater incentives to appoint non-partisans when the economy is in crisis. Bureaucratic quality does not seem to affect cabinet partisanship when all systems are compared, nor does the age of democracy matter. We repeated this model, serially excluding each regime as a base category, and consistently found that only presidentialism is associated with a significantly larger proportion of non-partisan ministers. ${ }^{10}$

\section{Exploring Cabinet Coalescence}

Do similar differences emerge in terms of cabinet coalescence, the degree to which the proportion of ministers per party corresponds to the proportion of seats each party holds in the coalition? Cabinet coalescence is analogous to Rose's index of 
disproportionality (Rose 1984), which measures the degree of deviation from strict proportionality between seats and votes that a given electoral rule produces. For cabinet coalescence, ministries and seats replace seats and votes. The formula is:

$$
\operatorname{COALESCENCE}=1-1 / 2 \sum_{\mathrm{i}=1}^{\mathrm{n}}\left(\left|\mathrm{M}_{\mathrm{i}}-\mathrm{S}_{\mathrm{i}}\right|\right)
$$

where $M_{i}$ is the percentage of ministries party $i$ receives when the cabinet is formed and $S_{i}$ is the percentage of legislative seats party $i$ holds of the total of seats commanded by the parties joining the cabinet when the cabinet is formed.

To calculate coalescence, add up the $\mathbf{M i}$ - Si | values for all parties joining the cabinet, whether or not these parties hold legislative seats, and for all ministers, whether party members or not, and then divide the total by two. Subtracting the result from 1 yields the degree of coalescence. The index varies between 0 (absolutely no proportionality between ministerial payoffs and legislative seats) and 1, which defines an upper limit of perfect correspondence between cabinet shares and legislative weight. For example, if a party gets half of the portfolios and has half of the seats that make up the legislative coalition in the legislature, then coalescence, as Amorim Neto (2006) prefers to term it - will equal one. If a party has all the portfolios and no seats, proportionality equals zero. Coalescence requires that at least one minister be a party member. If all ministers were non-partisans, the index would yield the value of 0.5 , a figure that does not correspond to a totally "disproportional" cabinet. We thus assign a value of zero for cabinets with no partisan ministers. Table Five again lists each country, this time with the average rate of proportionality per country in ascending order in two columns.

Table 5. Average Cabinet Coalescence by Country

\begin{tabular}{llllll}
\hline Country & Regime Type & Avg. Coalescence & Country & Regime Type & Avg. Coalescence \\
\hline Ecuador & PRES & 0.30 & Austria & SEMI & 0.88 \\
\hline Brazil & PRES & 0.52 & Denmark & PARL & 0.89 \\
\hline Venezuela & PRES & 0.56 & Luxembourg & PARL & 0.89 \\
\hline Estonia & PARL & 0.57 & Turkey & PARL & 0.90 \\
\hline USA & PRES & 0.58 & Argentina & PRES & 0.90 \\
\hline Peru & PRES & 0.61 & Macedonia & SEMI & 0.90 \\
\hline Poland & SEMI & 0.61 & Namibia & SEMI & 0.91 \\
\hline Czech & PARL & 0.65 & Finland & SEMI & 0.91 \\
\hline Bolivia & PRES & 0.72 & Slovenia & SEMI & 0.92 \\
\hline Czechoslovakia & PARL & 0.73 & Spain & PARL & 0.92 \\
\hline Panama & PRES & 0.75 & Portugal & SEMI & 0.92 \\
\hline India & PARL & 0.77 & Ireland & SEMI & 0.93 \\
\hline Uruguay & PRES & 0.77 & Japan & PARL & 0.94 \\
\hline Belgium & PARL & 0.78 & Netherlands & PARL & 0.95 \\
\hline Latvia & PARL & 0.81 & Sweden & PARL & 0.95 \\
\hline Italy & PARL & 0.81 & Norway & PARL & 0.95 \\
\hline Israel & PARL & 0.82 & Greece & PARL & 0.97 \\
\hline France & SEMI & 0.84 & Mexico & PRES & 0.97 \\
\hline Chile & PRES & 0.84 & Sri Lanka & SEMI & 0.97 \\
\hline Iceland & SEMI & 0.85 & Australia & PARL & 0.97 \\
\hline Switzerland & PARL & 0.86 & Lithuania & SEMI & 0.97 \\
\hline Colombia & PRES & 0.87 & Costa Rica & PRES & 0.98 \\
\hline Hungary & PARL & 0.87 & Jamaica & PARL & 0.99 \\
\hline Romania & SEMI & 0.87 & Botswana & PARL & 1.00 \\
\hline Slovakia & PARL & 0.87 & Guyana & PARL & 1.00 \\
\hline South Africa & PARL & 0.88 & PARL & 1.00 \\
\hline New Zealand & PARL & 0.88 & UKalta & PARL & 1.00 \\
\hline Germany & PARL & 0.88 & PARL & 1.00 \\
\hline Bulgaria & SEMI & 0.88 & & \\
\hline & & & & \\
\hline
\end{tabular}


Although three pure presidential countries exhibit the lowest degree of average coalescence (Ecuador, Brazil, Venezuela), and several parliamentary republics or monarchies exhibit perfect coalescence all the time, the differences across regimes do not pop out nearly as much as in Table Two. To better discover whether coalescence differs by regime, we first calculated the average coalescence for each regime, shown in Table Six.

Table 6. Average Coalescence by Regime Type

Regime Type $\quad$ Coalescence (Std. Dev.)

\begin{tabular}{ll} 
Parliamentary & $.883(.106)$ \\
\hline Semi-Presidential & $.883(.088)$ \\
\hline Presidential & $.718(.194)$ \\
\hline
\end{tabular}

Although parliamentary systems and semipresidential systems all have similar degrees of cabinet coalescence, presidential systems again differ. We then subjected this finding to multivariate analysis. The regressions that follow use average cabinet coalescence for each country as the dependent variable but include the same independent variables as for the regressions on cabinet partisanship. As with partisanship, we expect cabinet proportionality to decline as legislative fragmentation increases because it will be more costly not only to put together a majority government, but also politically more problematic to evenly divide the spoils across all coalition members. ${ }^{11}$ We again exclude parliamentary systems as the base group. As with partisanship, this variable is bounded between zero and one, so an appropriate regression technique is Tobit. The results appear in Table Seven.

Table 7. Factors Associated with Cabinet Coalescence (Tobit Regression)

\begin{tabular}{lcccc}
\multicolumn{1}{c}{ Variable } & Coefficient (S.E.) & $p>|\mathbf{t}|$ & Coefficient (S.E.) & $p>|\mathbf{t}|$ \\
\hline Presidential & $-.149(.055)$ & .009 & $-.186(.042)$ & .000 \\
\hline Semipresidential & $0.18(.037)$ & .629 & $.011(.037)$ & .759 \\
\hline Legislative Fragmentation & $-.049(.009)$ & .000 & $-.049(.010)$ & .000 \\
\hline Bureaucratic Quality & $-.036(.023)$ & .121 & $-.032(.023)$ & .168 \\
\hline Age of Democracy & $.0001(.001)$ & .442 & $.001(.001)$ & .237 \\
\hline Economic Growth & $.012(.006)$ & .081 & $.011(.007)$ & .120 \\
\hline Executive Powers & $-.006(.006)$ & .315 & -- & - \\
\hline Constant & $1.144(.071)$ & .000 & $1.118(.067)$ & .000 \\
\hline $\mathrm{N}$ & 57 & & 57 & \\
\hline LR chi-squared & 48.53 & & 47.52 & \\
\hline$p>$ chi-squared & 0.000 & & 0.000 & \\
\hline Log-likelihood & 40.836 & & -1.434 & \\
\hline pseudo-r ${ }^{2}$ & -1.465 & & & \\
\hline
\end{tabular}

Dependent variable: cabinet coalescence (1 is perfectly coalescent)

Results again support our main claim that the main difference across regimes is between presidentialism and all other democratic systems. Cabinet portfolio allocation is far less coalescent under presidentialism relative to the base category, while semi-presidentialism does not differ from parliamentarism substantially. We again repeated this exercise excluding each dummy variable serially, and found that presidentialism differs from all the other regime types, but none of the other regimes differ from each other. Legislative fragmentation has the predicted effect on cabinet coalescence, but none of the other control variables have substantial effects. ${ }^{12}$ In short, although small differences in the average degree of cabinet coalescence exist in systems in which the cabinet is dependent on legislative confidence (Carroll and Cox 2007), when one takes a broader view of the extent of cabinet coalescence, presidentialism stands out as permitting far greater variation. Executives under pure presidentialism have the greatest leeway to appoint cabinets in their own image, whereas prime ministers' options under parliamentarism and semi-presidentialism are far more constrained by the distribution of legislative seats.

\section{Discussion}

Scholars have long recognized that cabinets provide a critical link between the executive and legislative branches, and that cabinet dynamics are intimately related to variations in policy output. This paper explains variation in the incentives chief executives face to appoint partisans or non-partisans to cabinet ministries and whether to do so proportionally or not. Although differences in cabinet partisanship and proportionality exist across all democratic regimes, our results suggest that the strength of such 
incentives mainly differs between presidentialism and all other democratic systems. Prime ministers nearly always appoint wholly partisan cabinets because they depend wholly on parliamentary parties for their survival and success. In semipresidential systems, because the chief of state is elected independently and often influences cabinet appointments, we see slightly greater proportions of non-partisans and somewhat greater variation in terms of cabinet coalescence. However, cabinet dynamics in pure presidential systems differ most clearly from all the rest. Because of the separation of survival and because presidents often possess powerful tools to implement their goals without fear of being tossed from office, legislative parties have relatively less control over the policy process in presidential systems than in other systems of government. This opens the door for presidents to appoint more non-partisans to cabinet ministries and to vary the degree of cabinet coalescence to a far greater degree than in other political systems.

Relatively little research has explored variation in cabinet dynamics across democratic systems. Our findings clearly suggest that presidential cabinets provide a far more tenuous link between the executive and legislative branches of government. The separation of survival, presidents' position as formateur, their independent control over cabinet appointments and their varying unilateral powers all suggest that the expected "office" and "policy" payoffs to a party's participation in government differ substantially across regimes (Strøm 1990; Samuels 2002). Separation of survival means that the president always has the last word in cabinet nominations, whereas under parliamentarism the PM may have to concede de facto control to coalition partners (Laver and Shepsle 1996). Thus under presidentialism, parties considering whether to join a cabinet have greater cause to worry that they will be unable to translate participation into real policy influence.

Our findings suggest that as one moves from parliamentary to pure presidential systems the key differences in terms of cabinets may not be the size of the coalition or the number of coalition members (i.e. whether it is single- or multi-party). Under pure presidentialism, the type of cabinet indicated by the cabinet's degree of partisanship and coalescence - may be more important, because both are related to governance style and, possibly, success.

Coalitions frequently form in all systems of government. However, cabinet dynamics under presidentialism differ distinctly from what we observe in other systems. This holds for singleparty governments as well, because presidents' independent survival and autonomous powers mean that the relationship between even a single-party legislative majority and the "government" may differ substantially under the separation of powers. In sum, the connection between cabinet dynamics and government output is important, but the factors that matter go beyond the "usual suspects" of coalition size and/or fragmentation. Critical factors include the way in which presidents distribute portfolios to partisans or non-partisans and the degree to which that distribution corresponds proportionally to the contribution of actors in the presidents' support coalition. Research exploring the consequences of different constitutional regimes should look beyond the number of cabinet participants as a potential explanation for variations in governance across political regimes.

\begin{tabular}{l|c|c|c|c}
\hline \multicolumn{5}{c}{ Descriptive Statistics for Variables Included in Regression Analysis } \\
\hline \multicolumn{1}{c}{ Variable } & $\mathbf{N}^{*}$ & Mean (S.D) & Min. & Max. \\
\hline Partisanship & 59 & $.083(.144)$ & 0 & .65 \\
\hline Coalescence & 59 & $.841(.147)$ & 0.3 & 1 \\
\hline Legislative Fragmentation & 58 & $3.72(1.53)$ & 1.47 & 7.72 \\
\hline Bureaucratic Quality & 59 & $2.86(.98)$ & .49 & 4 \\
\hline Age of Democracy & 58 & $22.09(17.97)$ & .66 & 45.58 \\
\hline Economic Growth & 58 & $2.39(2.39)$ & -3.93 & 9.34 \\
\hline Executive Powers & 58 & $4.21(4.53)$ & 0 & 17 \\
\hline
\end{tabular}

\footnotetext{
${ }^{*} \mathrm{~N}=58$ or 59 because Colombia and Brazil are split into two periods due to constitutional changes, and/or because of missing data.
} 


\section{Notes}

1 Following Elgie (1999), we classify any country with a popularly elected president and a cabinet accountable to parliament as semi-presidential.

2 Therefore we eliminated countries that Woldendorp et al. included such as Pakistan, Bangladesh, and the pre-1994 cabinets of South Africa.

3 High standard deviations in countries with a cabinet accountable to parliament are due to the formation of caretaker governments, which are typically staffed by technocrats.

4 We also tested for an interactive effect between regime type and legislative fragmentation, but found none.

5 We explored this hypothesis with several additional measures of economic performance, including a measure of "recession," a dummy variable employed by Alesina and Perotti (1995). Using different indicators did not alter our results substantially.

6 Shugart and Carey quantitatively assess the formal powers of presidents through ordinal scales. Presidential powers are divided in two categories: legislative powers and non-legislative (appointment and dismissal) powers. There are six types of legislative powers: (1) package veto; (2) partial veto; (3) decree powers; (4) budgetary powers; (5) exclusive introduction of legislative in reserved policy areas; and (6) proposal of referenda powers. Each one of those 6 powers is assigned ordinal scores from 0 to 4 . Metcalf adds to the list of Shugart and Carey a seventh power, namely judicial review, whose scores also vary from 0 to 4 . The overall measure of presidential legislative powers is the sum of the scores on each of the seven powers.

7 We only include a measure of "legislative" powers. We also tested for the effect of "non-legislative powers," which include cabinet formation powers, cabinet dismissal powers, censure powers, and dissolution of assembly powers, but found that only the former proved important.

8 There are only 55 cases in Table Four (and 56 cases in Table 7) because we could not find information on legislative fragmentation for Czechoslovakia or for bureaucratic quality for Macedonia.

9 The difference between presidentialism and semi-presidentialism is significant only if the "autonomous powers" variable is not included in the regression. Taking these results together with the results in Table Four, in which the semi-presidential dummy was not significant, this suggests that variation in presidential powers is primarily responsible for variation in cabinet partisanship in semi-presidential systems, a finding that confirms previous research, whereas in pure presidential systems both regime type and presidential powers affect cabinet partisanship, relative to other systems.

10 We recognize that interacting "regime" variables with the "executive powers" variable might prove useful for teasing out whether one or the other is relatively more important. However, the high correlation between pure presidentialism and executive powers precludes conducting such a test. As noted, the correlation between presidentialism and autonomous powers is .74; the correlation between presidentialism and the interaction presidentialism*autonomous powers is .92. Introducing the interaction term in the regression thus provides little help.

11 Some of the impact of increased fragmentation may be "mechanical" because at some point it becomes impossible to further divide up portfolios into smaller and smaller bits. In this sense LEGFRAG is a control variable for both political and mechanical factors that are separate from regime effects.

12 We also tested for a logged effect of age of democracy, but found no effect. 


\section{References}

Aguayo Quezada, Sergio. 2000. El Almanaque Mexicano. México: Editorial Grijalbo.

Alesina, Alberto, and Roberto Perotti. 1995. "Fiscal Expansions and Adjustments in OECD Countries." Economic Policy 21:205-248.

Almeida, Acir, and Seok-ju Cho. 2003. "Presidential Power and Cabinet Membership Under Semi-Presidentialism." Paper presented at the meeting of the Midwest Political Science Association, Chicago.

Amorim Neto, Octavio. 2002. "Presidential Cabinets, Electoral Cycles, and Coalition Discipline in Brazil." In Legislative Politics in Latin America, ed. Scott Morgenstern and Benito Nacif. New York: Cambridge University Press.

Amorim Neto, Octavio. 2006. “The Presidential Calculus: Executive Policy Making and Cabinet Formation in the Americas." Comparative Political Studies 39(4):415-440.

Amorim Neto, 0ctavio, and Kaare Strom. 2006. “Breaking the Parliamentary Chain of Delegation: Presidents and Non-partisan Cabinet Ministers in European Democracies." British Journal of Political Science 36:619-643.

Argento, Anália, and Ana Gerschenson. 1999. Quién es Quién en la Política Argentina. Buenos Aires: Perfil Libros.

Banks, Arthur S., and Thomas C. Muller, eds. 1998. Political Handbook of the World. Binghamton: CSA Publications.

Baron, David P., and John Ferejohn. 1989. “Bargaining in Legislatures." American Political Science Review 83:11811206.

Blanco Bugand, Josefina, et al. 1991. Los Gabinetes Ministeriales Como Elites Políticas - Colombia (1930-1990), vol. 2. Bogotá: Universidad Javeriana.

Blondel, Jean, and Ferdinand Müller-Rommel, eds. 2001. Cabinets in Eastern Europe. New York: Palgrave.

Blondel, Jean. 2001. "Cabinets in Post-Communist East-Central Europe and in the Balkans: Introduction." In Cabinets in Eastern Europe, ed. Jean Blondel, and Ferdinand Müller-Rommel, New York: Palgrave.

Browne, Eric C., and Mark N. Franklin. 1973. "Aspects of Coalition Payoffs in European Parliamentary Democracies." American Political Science Review 67:453-469.

Budge, Ian, and Hans Keman. 1990. Parties and Democracy: Coalition Formation and Government Functioning in Twenty States. New York: Oxford University Press.

Carol, Royce, and Gary W. Cox. 2007. "The Logic of Gamson's Law: Pre-election Coalitions and Portfolio Allocations." American Journal of Political Science 51(2): 3003-313.

Druckman, James and Andrew Roberts. 2006. “Context and Coalition Bargaining: Comparing Portfolio Allocation in Eastern and Western Europe." Party Politics.

Elgie, Robert. 1999. “The Concept of Semi-Presidentialism and the Politics of Semi-Presidential Regimes. In Semipresidentialism in Europe, ed. Robert Elgie. 0xford: 0xford University Press.

Gamson, William A. 1961. "A Theory of Coalition Formation." American Sociological Review 26:373-382

Gonzales Diaz, Andres. 1982. Ministros del Siglo XX. Bogotá: Imprenta Nacional.

Graham, Lawrence. 1997. “Transients and Careerists in Latin America." In Modern Systems of Government: Exploring the Role of Bureaucrats and Politicians, ed. Ali Farazmand. Thousand Oaks: Sage Publications.

Gryzmala-Buse, Anna. 2001. "Coalition Formation and the Regime Divide in New Democracies: East Central Europe." Comparative Politics 34:85-104.

Keesing's Contemporary Archives. 1945-1990. London: Keesing's Publications.

Laakso, Marku, and Rein Taagepera. 1979. "Effective Number of Parties: A Measure With Application to West Europe." Comparative Political Studies 12:3-27.

Laver, Michael, and Kenneth A. Shepsle. 1996. Making and Breaking Governments. Cambridge: Cambridge University Press.

Linz, Juan J. 1997. “Introduction: Some Thoughts on Presidentialism in Postcommunist Europe”. In Postcommunist Presidents, ed. Ray Taras. New York: Cambridge University Press.

Mainwaring, Scott, Daniel Brinks and Aníbal Pérez-Líñán. 2001. “Classifying Political Regimes in Latin America, 1945-1999." Studies in Comparative International Development 36:37-65.

Mesa Gisbert, Carlos D. 1990. Presidentes de Bolivia: Entre Urnas y Fusiles. La Paz: Editorial Gisbert y Cia.

Molineli, Guillermo N., M. Valeria Palanza and Gisela Sin. 1999. Congreso, Presidencia y Justicia en Argentina. Buenos Aires: Temas Grupo Editorial SRL. 
Müller, Sean. 2006. Presidential Power in Semi-Presidential Systems: The Case of Romania. MA thesis defended at the University of Freiburg. Available at http://www.federalism.ch/files/documents/THESIS_final.pdf.

Müller, Wolfgang C., and Kaare Strom, eds. 2000. Coalition Governments in Western Europe. 0xford: 0xford University Press.

Nohlen, Dieter, ed. 1993. Enciclopedia Electoral Latinoamericana y del Caribe. San José: Instituto Interamericano de Derechos Humanos.

Nohlen, Dieter, Florian Grotz, and Christof Hartmann, eds. 2001. Elections in Asia and the Pacific: A Data Handbook, Vol II. New York: Oxford University Press.

Nohlen, Dieter, Michael Krennerich, and Bernhard Thibaut, eds. 1999. Elections in Africa: A Data Handbook. New York: Oxford University Press.

Olmos, Helena. N.d. Ministros de la Democracia. Caracas: Instituto Autonomo Biblioteca Nacional - Colección de Publicaciones Oficiales.

Peters, B. Guy. 1997. "Bureaucrats and Political Appointees in European Democracies: Who's Who and Does It Make Any Difference?" In Modern Systems of Government: Exploring the Role of Bureaucrats and Politicians, ed. Ali Farazmand. Thousand Oaks: Sage Publications.

PRS Group, Inc. 2004. "International Country Risk Guide." Microsoft Excel database and documentation. Proprietary data available through www.prsgroup.com.

Rauch, James, and Peter Evans. 2000. "Bureaucratic Structure and Bureaucratic Performance in Less-Developed Countries." Journal of Public Economics 75:49-71.

Rowland, Michael. 2002. Miembros del Gabinete 1979-2002. Quito: Proyecto Gobernabilidad CORDES.

Samuels, David. 2002. "Presidentialized Parties: The Separation of Powers and Party Organization and Behavior." Comparative Political Studies 35(4):461-483.

Schleiter, Petra, and Edward Morgan-Jones. 2009. "Party Government in Europe? Parliamentary and Semipresidential Democracies Compared." European Journal of Political Research 48:665-693

Strom, Kaare. 1990. "A Behavioral Theory of Competitive Political Parties." American Journal of Political Science 34:565-598.

Tuesta Soldevila, Fernando. 1994. Perú Político en Cifras. Lima: Fundación Friedrich Ebert.

Van Cranenburgh, Oda. 2006. "Namibia: Consensus Institutions and Majoritarian Politics." Democratization 13:584-604.

Warwick, Paul V., and James N. Druckman. 2001. "Portfolio Salience and the Proportionality of Payoffs in Coalition Governments." British Journal of Political Science 31:627-649.

Wilson, A. Jeyaratnam. 1980. The Gaullist System in Asia: The Constitution of Sri Lanka. London: Palgrave.

Woldendorp, Jaap, Hans Keman and Ian Budge. 2000. Party Government in 48 Democracies (1945-1998): Composition - Duration - Personnel. Dordrecht: Kluwer Academic Publishers.

World Bank. 2006. World Development Indicators 2006. Washington DC: World Bank. 


\begin{tabular}{|c|c|}
\hline Variable & Sources \\
\hline Legislative Fragmentation & $\begin{array}{l}\text { Muller and Strom (2000), Nohlen (1993), Nohlen et al. (1999), Nohlen et al. } \\
\text { (2001), and data provided by Arend Lijphart and Dieter Nohlen. }\end{array}$ \\
\hline Cabinet Appointment Data & 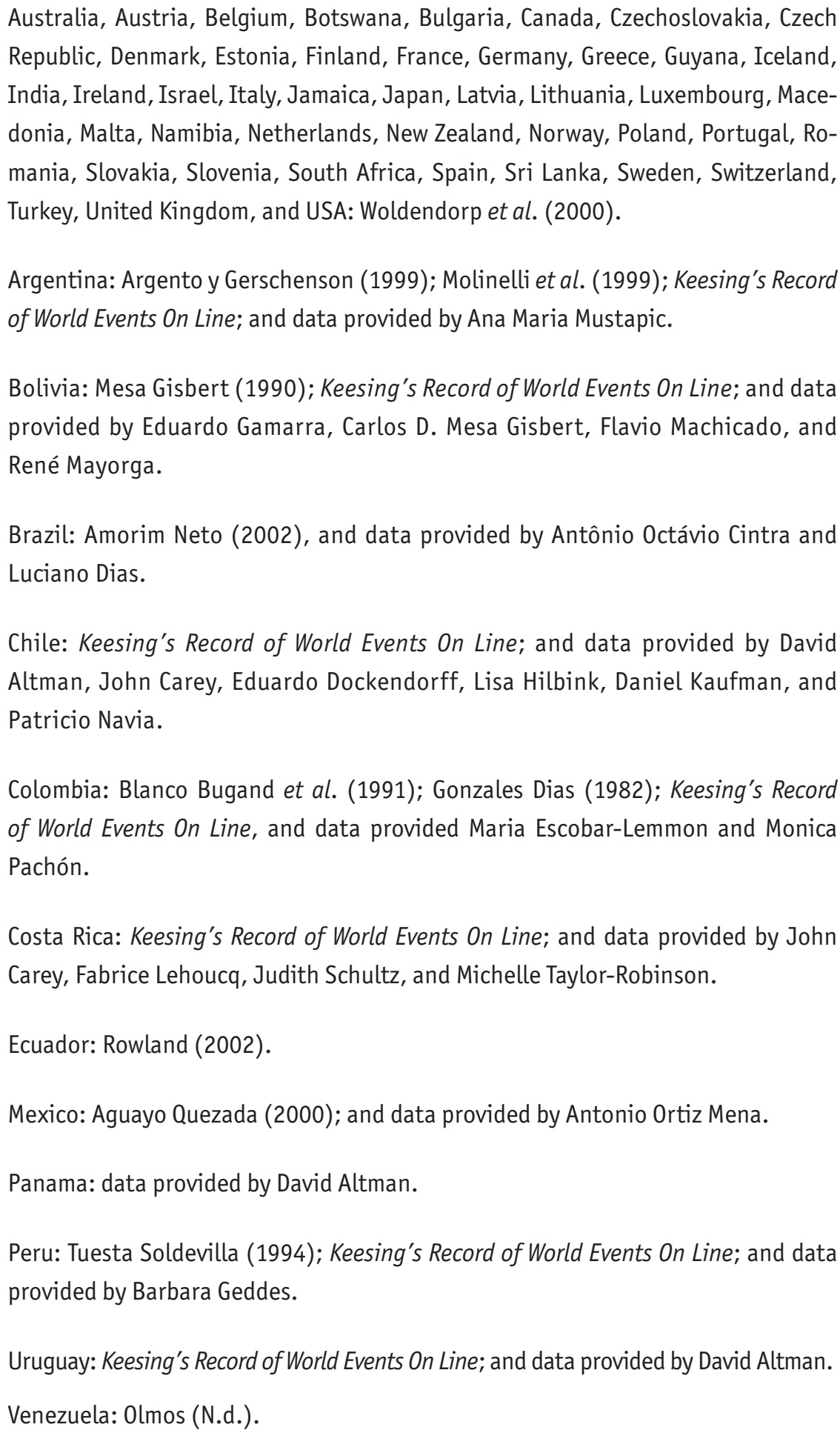 \\
\hline
\end{tabular}


Our primary source for the classification of the heads of state's constitutional powers was the online database maintained by the University of Richmond (http://confinder.richmond.edu/index.php), where all constitutions we analyzed can be found. Nonetheless, additional research was conducted to verify the quality of the information provided by that database.

Coding a constitutional power given to a head of state is, in itself, a subjective enterprise, for it requires a certain degree of interpretation. Also, in some countries the exercise of formal powers sometimes contradicts what is stipulated in the constitution. These were the most common instances of difficulty we found.

In Namibia, for example, the Constitution allows for the dismissal of cabinet members by a decision of the head of state alone. However, the constitution also stipulates the possibility of dismissal of cabinet members by a noconfidence vote taken by the National Assembly (Van Cranenburgh 2006). In this case, our coding was based on what the head of state is allowed to do, both formally and in practice.

When classifying heads of states' powers in Sri Lanka, the available literature suggests that a coding based exclusively on formal powers does not fully account for the powers made available to the chief of state, specially when we consider the extensive emergency powers at the latter's disposal. The president enjoys considerable latitude when deciding to use such powers (Wilson 1980).

In addition, Romania is an example of a country where the head of state acts after consulting parliament. In such a case, it is not clear whether the opinion expressed by the assembly is binding or not. The available literature on this country is very limited, the only text on the topic we found being Müller (2006). In Romania the main debate is on the power of convoking referenda. In this case we decided to stick to a formal reading of the Constitution.

In short, whereas in the vast majority of cases the constitutions and the accompanying literature are rather clear regarding where the limits of heads of state's constitutional powers lie, the aforementioned cases exemplify the rare instances in which our coding could be up for debate. 